\title{
Ancient Armenia: Evidence And Models
}

\author{
Giusto Traina \\ iD http:/orcid.org/0000-0002-7377-0562
}

Sorbonne Université

\begin{abstract}
The history of the kingdom of Greater Armenia (after 188 BCE-428 CE) has been generally interpreted from two different standpoints, an 'inner' and an 'outer' one. Greater Armenia as a marginal entity or a sidekick of Rome during the endless war with Iran, and even Iranian scholars neglected or diminished the role of Armenia in the balance of power. This paper discussed some methodological issues.
\end{abstract}

Keywords: Ancient Armenia, Roman History, Iranian History, Politology, Historical Methodology.

In his review of Moses Finley's last book, Ancient History: Evidence and Models, the classicist David Konstan resumed the main thesis of the book:

there are adequate concepts or models (Finley seems to use these terms interchangeably), but they cannot be confirmed by a satisfactory body of evidence. Nor is it a matter of simply waiting for more facts and figures to come in from the researches of anthropologists, papyrologists, epigraphers, and the like. The evidence will never exist . . . let us at least not ignore the models, both qualitative and quantitative, that are available, for that is to sacrifice the tools we have to the naive belief that evidence (whatever its condition) tells its own story. ${ }^{1}$

Both Finley and Konstan focused on the Classical world, but their methodological discourse may be confirmed for more eccentric and marginal realities. This is the case of ancient Armenia.

The history of the kingdom of Greater Armenia (after 188 BCE-428 CE) has been generally interpreted from two different standpoints, an 'inner' and an 'outer' one. ${ }^{2}$ The former approach is more usual among Armenian scholars, ${ }^{3}$ the latter is more familiar to the historians of Rome, and mostly concerns the role of Armenia in a general geopolitical context. Roman historians have been little attracted by the "inner" standpoint,

Konstan 1988, on Finley 1985 (see also Finley 1975, 118).

2 Ałayan et al. 1971; Ałayan et al. 1984; Garsoïan 1997; Chaumont, Traina 2008; Mahé, Mahé 2012, 19-103.

3 Chaumont 1976. 
which concerns the balance of power within the Armenian king and his vassal principalities (naxarar), ${ }^{4}$ except when it encroaches on their understanding of Armenian international relations. Armenology has mostly developed this situation, although, for the Pre-Christian period, i.e. before the 4th century CE, evidence is more fragmentary, or is conditioned by the peculiar standpoint of Armenian sources, that follow different logics. Therefore, it is very difficult to evaluate the real stakes of the balance of power. Indeed, the new trends in Roman history now focus on a "decolonized" image of the empire. ${ }^{5}$ Yet it is difficult to establish an ancient history which is also open to Armenia, as we have rich sources, but sources which are very difficult to handle. In a few words, we can establish a sort of a parallelism between Armenian and Roman history, but it is more difficult to study both situations at the same time. As a result, ancient historians, and Iranian scholars as well, show resilience when it comes to integrate Armenia into their world view, but that they failed to do so, and that Armenian scholarship continued to be conducted in isolation from wider historiographical trends: this can be seen in a recent historian such as Ruben Manaseryan. ${ }^{6}$ Despite the fact that historical research in the Republic of Armenia is now living a new, exhilarating phase of liberation from Marxist ideologies (with some exaggerated positions, mostly held by amateurs without a professional historical formation), Armenian historiography is often parochial and conservative, rejecting theoretically-informed approaches as essentially ahistorical. Moreover, as a reflex of Western overspecialization, within the younger generations there is scarce communication between historians and philologists.

On the other hand, ancient historians and archaeologists usually consider Greater Armenia as a marginal entity or a sidekick of Rome during the endless war with Iran; ${ }^{7}$ even Iranian scholars neglected or diminished the role of Armenia in the balance of power. ${ }^{8}$ Of course, we would hardly call ancient Armenia a "protectorate" (as Lord Curzon did in $1907^{9}$ ): the expression "indirect suzerainty" is more politically correct, but the anachronistic cliché of a Greater Armenia as a "buffer state" often recurs in both popular and scientific literature. ${ }^{10}$ In a statement which found some popularity among political scientists, Edward Luttwak said that "only Armenia was a true buffer state, serving as a physical neutral zone between the greater powers of Rome and Parthia, and providing them with a device that would serve to avoid conflict as long as they desired to avoid conflict." ${ }^{11}$ But this analysis reflects the modern perspectives, where all Transcaucasia is

4 See Toumanoff 1963; Adontz 1970; Garsoïan, Mahé 2000.

5 See e.g., Woolf 2012.

6 Manaseryan 1987, 1997.

7 As for the archaeological tradition, see Kéfélian 2020. Among some important exceptions we may mention the late Marie-Louise Chaumont, the first Western Classicist who tried to embed the Armenian literary sources in a general approach to Armenian history, whereas other scholars strongly denied the value of some important authors, such as Movsēs Xorenac'i. No wonder that Armenian scholars usually marginalize Chaumont's works, above all Chaumont 1969, 1976, and several valuable papers (e.g. Chaumont 1984; Chaumont 1985-1988; Chaumont 1989; Chaumont 2001-2002).

8 Traina 2018a, 107.

9 Curzon 1907, 38-39.

10 Traina 2018b. See, e.g., Grygiel 2015.

11 Luttwak 2016, 24; see also 118, 131. An interesting example is Gruen 1996, who first speaks of "indirect suzerainty" (158), but further on (160) mentions "the client state an buffer region of Armenia." Even 
still characterized as a buffer zone. ${ }^{12}$ Moreover, Luttwak's analysis is only valid for the Roman Principate; in his book on Byzantium, he overtly criticizes it for the later periods:

While often described as "buffer states" by modern historians, the evidence indicates that the autonomous existence of Armenian states between the two empires was more conflict-inducing than conflict-buffering, as both contended for authority over the fractious nakharars, the petty rulers of narrow valleys who made up political Armenia. ${ }^{13}$

In any case, the buffer model is most inadequate for the Armenian case. A buffer state is a small independent state lying between two larger, usually rival, states (or blocs of states). Armenia was independent: the ambiguous kingdom par excellence maintained its independence within a timeline of six hundred and fifty years, with some interruptions). However, it was certainly not a small state. It held a strategic position, a vast expanse of territory, and valuable natural resources. To neglect its role, or to diminish its position in the balance of power, is a mistake, as Armenia cannot be compared with invented buffer states like Afghanistan. With all due caution, the history of Greater Armenia may be compared with the history of Poland, which was not established as such but became later a buffer state, in the sense of a state geographically located between two other states engaged in a rivalry, with an important function in the balance of power. The failure to balance power brought the end of the Armenian state in 428, exactly as happened to the Polish kingdom in $1795 .{ }^{14}$ In fact, a country with a mixed identity such as Armenia does not fit easily into the dichotomous categories of 'East' and 'West', as it was not only between East and West, but also in East and West. Armenia's "ambiguity" raises some methodological problems, and not only for the ancient periods. The point was fairly stated by a modern historian, Jo Laycock: "Armenia does not fit easily into the dichotomous categories of 'East' and 'West' emphasized by [Edward] Said. Instead images of Armenia have been characterised by ambiguity and fluidity."15 The term 'ambiguity' recalls a famous passage of Tacitus, depicting Armenia as an ambigua gens, an expression which does not merely means "ambiguous people" but also holds the sense of an "uncertain people," whereas the real ambiguity stands in the policy of the Roman and Iranian superpowers. ${ }^{16}$

A fair solution consists in considering ancient Armenia as a connected history: twenty years ago, in his seminal article Sanjay Subrahmanyam criticized nationalism for blinding us to the possibility of connection. ${ }^{17}$ This could be a useful step to break the current paradigms, no matter to what extent they rest on Romanocentrism, nationalism, or parochialism. It will be necessary to shift current historical paradigms, and to highlight the value of the Armenian historiographical sources.

Garsoïan 1997, 55, depicts pre-Christian Armenia as a country slowly proceeding "to the status of a "buffer state', the opposing cultural and more ominously political pressures of the Mediterranean and Oriental worlds eventually increased, threatening at times its unity and it."

12 Asatryan 2002, 22.

13 Luttwak 2009, 49.

14 Fazal 2007, 116.

15 Laycock 2009, 220.

16 Tacitus, Ann. 2.56.1 (and 13.34.2 on the Armenians' ambigua fides), see Traina 2018b; Shirinyan 2019.

17 Subrahmanyam 1997, 761; see also Subrahmanyam 2019, 1-25. 
Armenia's connection to the West and East at the same time make it a challenging case, but potentially productive of exciting results. Regrettably, the few specialists on ancient Armenia hardly ever communicate with those other scholars. In the West, the Armenian scholars working on the classical and late antique periods are concentrated to their own discipline in a traditional "Orientalist" ghetto, showing little interest to new debates in ancient and late antique history as a whole. I would not say that all ancient historians in Europe are concerned with innovative themes: nonetheless, the best production in the history of ancient Armenia consists essentially in positivistic or antiquarian studies. There is, of course, nothing wrong with that. Unfortunately, in some cases this kind of research is essentially a sort of a Western restyling of the erudition developed during the 19th and 20th centuries in the Orientalist centers such as Venice, Moscow, Tiflis and, somehow later, Erevan. ${ }^{18}$

A major keyword is connectivity. Nina Garsoïan rightly pointed out that

Armenia's geographical position at the meeting point of Greco-Roman and Iranian worlds created a situation that favored the country's cultural life, enriched it with two major traditions but playing havoc with the continuity of its political history. As a general pattern, therefore, Armenia flourished only when the contending forces on either side were in near equilibrium and neither was in a position to dominate it entirely. ${ }^{19}$

This assumption, informally called by her students and colleagues as "Garsoïan's Law," may be now applied and expanded in a more global way, embedding Armenian history within a larger history including not only the Mediterranean, but also Eurasia. ${ }^{20}$

To shift the paradigm, a thorough revision of the literary evidence is needed. A very few moments of the history of pre-Christian Armenia can resist to the critical sieve of a rigid positivistic method. Our chronological and dynastic data are often imprecise. The literary and epigraphic sources on the kingdom of Armenia, and on its relations with the other kingdoms and powers, are relatively scarce. Over all, we lack "guide-texts" which could provide the historian with a space-temporal web of some precision. Even the most elaborated and thoughtful reconstruction - which Hakob Manandyan called the "critical history" of Armenia - necessarily stops in front of the limited number of sources. ${ }^{21}$ Classical sources therefore allow us to draw a more or less complete timeline. Yet, in order to create a different idea of ancient Armenia, it is of the utmost importance to study the ideological bias of the Classical sources. Ancient authors highlighted its ambiguity and fluidity. For example, one of the most popular definitions is Tacitus's label of the Armenian people as an ambigua gens, "ambiguous people/race," showing an "ambiguous loyalty" towards Rome (Annales, II, 53). This is more than the usual cliche of the untrustworthy Oriental: in fact, it made a good pretext to justify invasion. A keen observer of geopolitics and a master of style, Tacitus handled the multiple nuances of the adjective ambiguus. Although it can be translated as 'untrustworthy' or 'equivocal,' its principal meaning is 'uncertain,' 'vague,' 'undecided'. To sum up, the Armenians were

18 See Saint-Martin 1818-1819; Inǰijean 1822, 1835, and the interesting, although cryptic remarks by Nichanian 2014.

19 Garsoïan 1982.

20 Aslanian 2018, 112; see also Humphries 2017.

21 Manandyan 1945-1957. 
untrustworthy and undecided because they could not just choose between the Romans and the Iranians, who both desired to control their country. Similar expressions may be found in other passages by Greek and Latin authors, although they have not been fully analyzed, in the same way as Charlotte Lerouge did for the Parthians. ${ }^{22}$ Another good example is offered by the account of Armenian affairs narrated in the surviving books of Ammianus Marcellinus, covering events between 354 and 376. The considerable richness of Ammianus" "Armenian file" implicitly confirms the importance accorded by the historian to the kingdom. ${ }^{23}$

On the other hand, Classical sources present several documentary gaps which can be filled by the Armenian sources, even though these texts are of difficult use, owing to several anachronisms and contradictions, and cannot always be employed as positive evidence; in fact, it is difficult to compare the Greek and Roman sources with Armenian authors such as Agat'angełos, the Epic Histories (a.k.a. the Pseudo-Faustus of Byzantium), or Movsēs Xorenac'i. The latter is particularly complex, as he usually mixes local oral traditions with heterogeneous Greek and Roman sources; the result is a chronological hodgepodge. Such a documentary chaos aroused harsh criticisms, leading many scholars, especially in the West, to reject his historical value; an authoritative voice, such as Robert Thomson, remarks that Xorenac'i's History is not only controversial, but also basically untrustworthy. ${ }^{24}$

Nonetheless, Armenian sources cannot be ignored. Despite the poor reputation of Movsēs Xorenac'i, whose date is still under dispute, his History of Armenia allows us to reconstruct the structures of the kingdom. The Epic Histories, the main source for the history of the 4th century, is a less problematic source, but also needs to be properly 'decoded'. Armenian sources can represent a most valuable contribution to fill the gaps in the puzzle of the history of the kingdom. Of course, it would be absurd to put together in a positivistic frame the elements provided by, say, Strabo, Tacitus, or Movsēs Xorenac'i, without a thorough examination of all the problems presented by these texts. Moreover, the gaps in the historical narrative would never allow us to create a continuous account. ${ }^{25}$ By disavowing the Armenian "Father of History," we actually throw the baby out with the bath water. To exclude this "disturbing" source, as several Western scholars do, is not a solution. In fact, once Xorenac'i's History is properly "decoded," its historical value can be reassessed, as it actually yield solid factual information on the political history, on the social system of ancient Armenia, and also on some episodes of non-Armenian history. ${ }^{26}$

To sum up, the kingdom of Greater Armenia needs to be studied in a broader geopolitical context, as a case study of global history, in the same way as a new generation of armenologists is now working on a global approach to Medieval and Modern Armenian

22 Lerouge 2007.

23 Traina 2017a.

24 Thomson 1994.

25 My own studies on Xorenac'i's History of Armenia - in my opinion, a still misunderstood masterwork of late antique historio - graphyfollow the same research direction: Traina 1995-1998; Traina 1996 [1997]; Traina 2006 [2007]; Traina 2015.

26 T'opchyan 2001; T'opchyan 2006; Gazzano 2016; Mari 2016. 
history. ${ }^{27}$ As the late Jerry Bentley wrote, "World historians have not denied the significance of local, national and regional histories, but have insisted on the need to locate those histories in larger relevant contexts." 28

\section{BIBLIOGRAPHY}

Adontz, N. (1970), Armenia in the Period of Justinian: The Political Conditions Based on the naxarar System, Translated with Partial Revisions, a Bibliographical Note and Appendices by Nina G. Garsoïan, Lisboa.

Ałayan E. A. B. et al. (1971), Hay žołovrdi patmut 'iwn [History of the Armenian People], vol. I, Erevan. Ałayan E. A. B. et al. (1984), Hay žotovrdi patmut'iwn [History of the Armenian People], vol. II, Erevan.

Asatryan G. S. (2002), Armenia and Security Issues in the South Caucasus, Connections 1.3: 21-30.

Aslanian, S. (2018), From “Autonomous" to "Interactive" Histories: World History's Challenge to Armenian Studies, in: K. Babayan, M. Pifer (eds.), An Armenian Mediterranean, Basingstoke-New York: 81-125.

Babayan, K., Pifer, M. (eds.) (2018), An Armenian Mediterranean, Basingstoke-New York.

Bentley, J. (2011), Introduction: The Task of World History, in: J. Bentley (ed.), The Oxford Handbook of World History, Oxford: 1-18.

Chaumont, M.-L. (1969), Recherches sur l'histoire d'Arménie, de l'avènement des Sassanides à la conversion du royaume, Paris.

Chaumont M.-L. (1976), L'Arménie entre Rome et l'Iran I. De l'avènement d'Auguste à l'avènement de Dioclétien, $A N R W$ 9.1: 71-194.

Chaumont M.-L. (1984), L'expédition de Pompée le Grand en Arménie et au Caucase (66-65 av. J.-C.), Quaderni catanesi 6: 17-94.

Chaumont M.-L. (1985-1988), a propos des premières interventions parthes en Arménie et des circonstances de l'avènement de Tigrane le Grand, Acta Antiqua Academiae Scientiarum Hungaricae 31: 13-25.

Chaumont M.-L.(1988-1989), Quelques notes concernant Tigranocerte, Revue des Études Arméniennes, n.s. 21: 233-249.

Chaumont M.-L. (1989), Sur l'origine de Saint Grégoire d'Arménie, Le Muséon 102: 115-130.

Chaumont M.-L. (2001-2002), Tigrane le Jeune, fils de Tigrane le Grand. Révolte contre son pére et captivité à Rome, Revue des Études Arméniennes 28: 225-247.

Chaumont, M.-L., Traina, G. (2008), Les Arméniens entre l'Iran et le monde gréco-romain (Ve siècle av. J.-C. - vers 300 ap. J.-C., in: G. Dédéyan (ed.), Histoire du peuple arménien, Toulouse: 101-162.

Curzon, G. N. (1907), Frontier, Oxford.

Fazal, T. M. (2007), State Death: The Politics and Geography Annexation, Princeton.

Finley, M. I. (1975), The Use and Abuse of History, London.

Finley, M. I. (1985), Ancient History: Evidence and Models, London.

Garsoïan, N. (1982), Armenia, History of, in: J. R. Strayer (ed.), Dictionary of the Middle Ages, vol. 1, New York: 474.

27 See, e.g., Vacca 2017; Babayan, Pifer 2018 (especially the methodological observations by Aslanian 2018; Pogossian, Vardanyan 2019.

28 Bentley 2011, 2. 
Garsoïan, N. (1989), The Epic Histories Attributed to P'awstos Buzand (Buzandaran Patmut'iwnk'), Cambridge, Ma.

Garsoïan, N. (1997), The Emergence of Armenia; The Aršakuni Dynasty (A.D. 12-(180?)-428), in: R. G. Hovannisian (ed.), The Armenian People from Ancient to Modern Times, vol. 1: The Dynastic Periods: From Antiquity to the Fourteenth Century, New York: 37-62, 63-94.

Garsoïan, N. (2003-2004), L'Histoire attribuée à Movses Xorenac'i: que reste-t-il à en dire?, Revue des Études Armeniennes 29: 29-48.

Garsoïan, N., Mahé, J.-P. (2000), Des Parthes au Califat. Quatre leçons sur la formation de l'identité arménienne, Paris.

Gazzano, F. (2016), Croesus' Story in the History of Armenia of Movsēs Xorenac'i, in: F. Gazzano, L. Pagani, G. Traina, Greek Texts and Armenian Traditions, Berlin-New York: 83-114.

Gazzano, F., Pagani, L, Traina, G. (eds.) (2016), Greek Texts and Armenian Traditions, Berlin-New York.

Gruen, E. S. (1996), The Expansion of the Empire under Augustus, Cambridge Ancient History, vol. X: The Augustan Empire, 43 B.C.-A.D. 69, 2nd edition, Cambridge: 147-197.

Grygiel, J. (2015), Emperor Nero's Lesson on Ukraine, https://www.the-american-interest. com/2015/09/04/emperor-neros-lesson-on-ukraine/.

Harut'iwnyan, B. H. et al. (2004), Hayastani patmut'yan atlas [Atlas of the History of Armenia], vol. I, Erevan.

Humphries, M. (2017), Late Antiquity and World History: Challenging Conventional Narratives and Analyses, Studies in Late Antiquity 1: 8-37.

Inǰijean, Ł. (1822), Storagrut 'iwn hin Hayastan [Description of Ancient Armenia], Venezia.

Inǰjijean, Ł. (1835), Hnaxōsut'iwn ašxarhagrakan Hayastaneayc 'ašxarhi [Geographical Archaeology of the Armenian World], vol. I-III, Venezia.

Kéfélian, A. (2020), État des lieux de la recherche dans le Sud-Caucase : enjeux politiques et idéologiques, in: J.-P. Vallat, R. González Villaescusa, G. Traina (eds.), Les mondes romains. Questions d'archéologie et d'histoire, Paris: 419-426.

Konstan, D. (1988), Review of Finley 1985, History and Theory 27: 178-187.

Laycock, J. (2009), Imagining Armenia: Orientalism, Ambiguity and Intervention, Manchester.

Lerouge, C. (2007), L'image des Parthes dans le monde gréco-romain de la fin du Ier siècle av. J.-C. jusqu'à la fin du Haut-Empire romain, Stuttgart.

Luttwak E. N. (2009), The Grand Strategy of the Byzantine Empire, Cambridge, Ma.-London.

Luttwak E. N. (2016), The Grand Strategy of the Roman Empire: From the First Century CE to the Third, Revised and Updated Edition, Baltimore.

Mahé, A., Mahé J.-P. (2012), Histoire de l'Arménie des origines à nos jours, Paris.

Manandyan, H. (1945-1957). K'nnakan tesut' iwn hay žołovrdi patmut'yan [A Critical Overwiew of the History of the Armenian People], vol. I-II = Erker, vol. 1-2, Erevan 1977-1978.

Manaseryan, R. (1987), Tigran Mec. Hayastani Paykara Hromi ev Part 'ewstani dem [Tigran the Great: Armenia's Struggle against Rome and Parthia], Erevan.

Manaseryan, R. (1989), Hayastanə Artavazdic ' minč 'ev Trdat Mec [Armenia from Artawazd to Trdat the Great], Erevan.

Mari, F. (2016), Cyrus the Great in Movsēs Xorenac'i, Patmut'iwn Hayoc': Telescoping the King, in: F. Gazzano, L. Pagani, G. Traina, Greek Texts and Armenian Traditions, Berlin-New York: 115-152.

Nichanian, M. (2014), Mourning Philology: Art and Religion at the Margins of the Ottoman Empire, New York.

Pogossian, Z., Vardanyan, E. (eds.) (2019), The Church of the Holy Cross of Att 'amar, Leiden-Boston. Saint-Martin, A.-J. (1818-1819), Mémoires historiques et géographiques sur l'Arménie, vol. I-II, Paris.

Shirinyan, A. (2019), Armenia's Foreign Policy Balancing in an Age of Uncertainty, https://www. chathamhouse.org/publication/armenia-s-foreign-policy-balancing-age-uncertainty/2019-03-14Armenia3.pdf . 
Subrahmanyam, S. (1997), Connected Histories: Notes towards a Reconfiguration of Early Modern Eurasia, Modern Asian Studies 31: 735-762.

Subrahmanyam, S. (2019), Empires Between Islam and Christianity, 1500-1800, New York.

Thomson, R. W. (1994), Moses Khorenatsi, in: J. A. C. Greppin (ed.), Studies in Classical Armenian Literature, Delmar, N. Y.: 84-100.

Topchyan, A. (2001), Julius Africanus' Chronicle and Movsēs Xorenac'i, Le Muséon 114: 153-185.

Topchyan, A. (2006), The Problem of the Greek Sources of Movsēs Xorenac 'i's History of Armenia, Leuven-Paris-Dudley.

Toumanoff, C. (1963), Studies in Christian Caucasian History, Washington, D. C.

Traina, G. (1995-1998), Materiali per un commento a Movsēs Xorenac'i, Patmut'iwn Hayoc', Le Muséon 108: 279-333; 111: 95-138.

Traina, G. (1996), Archivi armeni e mesopotamici. La testimonianza di Movsēs Xorenac'i, in: M.-L. Boussac, A. Invernizzi (eds.), Archives et Sceaux du monde hellénistique, (Bulletin de correspondance hellénique, Supplément 29): 349-363.

Traina, G. (2004a), La frontiera armena dell'impero romano: i due punti di vista, in: C. Moatti (ed.), La mobilité des personnes en Méditerranée à l'époque moderne, vol. 1: Les passages de frontière, Roma: 205-222.

Traina, G. (2004b), Mythes fondateurs et lieux de memoire de L'Arménie pré-chrétienne (I), Iran \& The Caucasus 8: 169-181.

Traina, G. (2006 [2007]), Moïse de Khorène et l'Empire sassanide, in: R. Gyselen (ed.), Des IndoGrecs aux Sassanides : données pour l'histoire et la géographie historique, Leuven:158-179.

Traina, G. (2012), La production rurale dans la phase finale du royaume de la Grande Arménie: le témoignage de Moïse de Khorène, Antiquité tardive 20: 161-164.

Traina, G. (2015), Tradition et innovation dans la première historiographie arménienne, in: P. Blaudeau, P. Van Nuffelen (eds.), L'historiographie tardo-antique et la transmission des savoirs, Berlin-New York: $153-164$.

Traina, G. (2016a), L'impero di Tigran d'Armenia nella versione di Trogo-Giustino, in: A. Galimberti, G. Zecchini (eds.), Studi sull'epitome di Giustino. III. Il tardo ellenismo. I Parti e i Romani, Milano: 99-115.

Traina, G. (2016b), Traditions on Armenia in Submerged Greek Literature: Preliminary Considerations, in: G. Colesanti, L. Lulli (eds.), Submerged Literature in Ancient Greek Culture, vol. 2: Case Studies, Berlin-New York: 111-123.

Traina, G. (2017a), L'Armenia di Ammiano Marcellino, Electrum 24: 213-221.

Traina, G. (2017b), Quando i romani 'scoprirono' gli armeni: il re Tigran e la tigre (Varrone, ling. 5.100), in: S. Rocchi, C. Mussini (eds.), Imagines Antiquitatis: Representations, Concepts, Receptions of the Past in Roman Antiquity and the Early Italian Renaissance, Berlin-Boston: 39-47.

Traina, G. (2018a), The Rise of the Sassanians, in: T. Daryaee (ed.), Sasanian Iran in the Context of Late Antiquity, Irvine, Ca.: 107-115.

Traina, G. (2018b), Ambigua Gens? Methodological Problems in the Ancient Armenian History, in: H. Berberian, T. Daryaee (eds.), Reflections of Armenian Identity in History and Historiography, Irvine, Ca.: 63-71.

Traina, G. (2018c), Les inscriptions grecques d'Armawir (Arménie): considérations préliminaires, in: S. Magnani (ed.), Domi forisque. Omaggio a Giovanni Brizzi, Bologna: 291-306.

Traina, G. (2020), 428, une année ordinaire à la fin de l'Empire romain, Nouvelle édition revue et corrigée, Paris.

Trever, K. V. (1953), Očerki po istorii drevnej Armenii (II v. do n.è-IV v. n.è) [Essays on the History of Ancient Armenia (II BCE-IV CE)], Moskva-Leningrad.

Vacca, A. (2017), Non-Muslim Provinces under Early Islam: Islamic Rule and Iranian Legitimacy in Armenia and Caucasian Albania, Cambridge-New York.

Woolf, G. (2012), Rome: An Empire's Story, Oxford. 